\title{
Donald P. Kommers: Teacher, Translator, Trailblazer
}

\author{
By Justin Collings*
}

\section{A. Introduction}

It's not often that a single homework assignment alters the course of one's professional life. But that's what happened to me when, in a comparative law seminar during my student days, we were asked to read the Lüth judgment of the German Federal Constitutional Court. We read the judgment in translation, of course. And the translation, of course, was that of Donald Kommers. I'm not sure how well I understood the judgment at the time, but I did sense something of the decision's scope and depth, and of the Court's awareness that it was doing something momentous. I became fascinated by the German Court and wanted to know more. In those days of discovery, before I learned German, Donald Kommers (and his casebook) was my unfailing and surefooted interpreter and guide. ${ }^{1}$

Later, I learned German. And as a doctoral candidate I took a stab at writing the Court's history. At some point in that process, I decided, perhaps misguidedly, that I needed to forge my own path in the original sources, independent of the writings of Donald Kommers. Still, I looked to Professor Kommers as the founder of my field-as German constitutionalism's first and foremost foreign commentator and explicator. I had completed a draft of my book before I finally reached out to Professor Kommers directly. I did so with some trepidation, worried, I suppose, that he would see me as a rival or (more likely) an upstart.

I could not have been more wrong. Don read my manuscript at lightning speed and responded with generosity, warmth, encouragement, and help. He passed on a supportive word to a prospective publisher, which surely played an important role in transforming my dissertation into a published book. ${ }^{2}$ In his characteristic modesty, Don assured me that his intervention was no big deal because, as he put it, the book "stood on its own bottom." That was the beginning of a warm exchange that, for me at least, was far too brief. Don lived a good life and a long one, but for his epigones like me, the end came too soon. His departure means the loss of a teacher and a mentor, an inexhaustible fund of knowledge, and a friend.

\section{B. Teacher}

The third edition of Don's casebook, published this time with Russell Miller as co-author, came out while I was working on my dissertation. ${ }^{3}$ I could hardly wait to get my hands on it. When I did, I was amazed by how much it taught me. I was becoming, by this time, something of an expert on the topic myself. But I noticed then, and have often noticed since, that the more I learn about German constitutionalism the more I learn from what Don has written before me. The less I think

\footnotetext{
${ }^{*}$ Associate Professor of Law, J. Reuben Clark Law School, Brigham Young University.

${ }^{1}$ See Donald P. Kommers, The Constitutional Jurisprudence of the Federal Republic of Germany (2d ed., 1997).

${ }^{2}$ See Justin Collings, Democracy's Guardians: A History of the German Federal Constitutional Court, 1951-2001 (2015).

${ }^{3}$ See Donald P. Kommers \& Russell A. Miller, The Constitutional Jurisprudence of the Federal Republic of GERMANY (3d ed., 2012).
}

() 2019 The Author. Published by Cambridge University Press on behalf of the German Law Journal. This is an Open Access article, distributed under the terms of the Creative Commons Attribution licence (http://creativecommons.org/licenses/by/4.0/), which permits unrestricted reuse, distribution, and reproduction in any medium, provided the original work is properly cited. 
I need his various introductions to the German Court and constitution, the more impressed I am by how superb they are. I never took a class from Don, but in his writings at least, he was a master teacher. I am grateful to have been his student.

\section{Translator}

Don's role as teacher fused seamlessly with his role as translator-and I use the term "translator" in its most capacious sense. Yes, Don did the world an enormous service by rendering scores of German judgments into elegant, accessible English. To sense just how great a service that was, one need only read a few pages of one of the Court's official English translations, and then compare it with one of Don's. The transition is one from dense and jarring literalism to refreshingly readable English. As a translator, Don never sacrificed substance to style-but he never forgot about style. Hugh Trevor-Roper once warned historians that, "You may read all the documents in the world, but if you do not have sense you will not be right, and if you do not have style you will not be read." " Don had sense and style in spades. His superb translations will not soon be supplanted or surpassed.

But Don was a translator in a far broader sense than transforming seminal German judgments into agreeably lucid English prose. For the benefit of all of us, Don transmitted not only judicial texts, but an entire constitutional culture. His collected scholarship on German constitutionalism provides an extended course in cultural immersion. He was a steady, sure-handed, supremely intelligent guide.

What made his work so good? Many, many things. But I can highlight a few of them by reference to Don's jubilee commemoration of the Basic Law, published at the turn of the millennium in the SMU Law Review and republished in this memorial collection. ${ }^{5}$

The essay begins with Don at his best, capturing the essence of the Basic Law, both structural and substantive, in fewer than five pages. Like so much of Don's work, it is a model of clarity and concision. He uses very little space and leaves very little out. Also characteristic of Don's scholarship, the summary is informed and infused by a deep sensitivity to the broad sweep of German history-its crises and convulsions, its continuities and collapses, its catastrophes and recommencements. Further evident is Don's careful attention to patterns and principles-his observation, for instance, that German constitutionalism speaks "far more than the American Constitution . . . in the language of responsibilities as well as rights," 6 or his delineation of the Basic Law's structural pillars (popular sovereignty, federalism, separation of powers, the rule of law, competition among parties, etc.) and their mutual reinforcement. ${ }^{7}$

Don's jubilee piece also shares with his broader scholarship a deep understanding of both the structure and the doctrine of German constitutionalism-both the system's workings and the Court's jurisprudence. Don paid more attention than most comparatists to the Basic Law's text, but was also keenly aware of the legal and political contexts in which it was embedded. Few, even in Germany, could match his mastery of the Constitutional Court's jurisprudence. But he never made the mistake of regarding the Court as an island oasis far from the madding crowd of political wrangling and party strife. Don never wrote about the Karlsruhe Court without one eye fixed on Bonn (later Berlin) and the other on German society. Don's studies of German constitutionalism were always also studies of Germany itself-its people and its past, its problems and its possibilities.

Don was an original scholar, a fact that many might underestimate because Don never saw the need to highlight his own originality. Many legal scholars feel compelled, perhaps for the sake of

\footnotetext{
${ }^{4}$ Hugh Trevor-Roper, The Wartime Journals 154 (Richard Davenport-Hines, ed., 2012).

${ }^{5}$ See Donald P. Kommers, The Basic Law: A Fifty Year Assessment, 53 S.M.U. L. Rev. 477 (2000).

${ }^{6} I d$. at 478 .

${ }^{7} I d$. at $478-9$.
} 
student editors, to trumpet their contributions at least three times-abstract, introduction, conclusion. Sometimes more. But for Don it was enough to marshal the relevant evidence, to elicit therefrom the most reasonable conclusions, and to present his evidence and argument in as clear, straightforward, and compelling a manner as he could. And he could be very clear, impressively straightforward, and exceptionally compelling.

He was never self-assertive. Don's jubilee piece provides an original (to my knowledge) chronology and context for the Basic Law's various waves of textual amendment. The account is interesting, uncluttered, and extremely helpful. But Don never bothered to mention that he was doing something new. He wouldn't have seen the point in that. His goal was to understand the German constitutional order and to help others understand it. In this respect he was always, and again, a consummate translator and a constant teacher. A translator can commit no graver sin than to draw attention to the translation. And the best scholars, like the best teachers, think least about themselves. William Hazlitt once voiced his preference for Sir Walter Scott over Lord Byron (and others) on the ground that Scott was forever "thinking of [his subject], and not of himself, while he [wrote]." ${ }^{\prime 8}$ Donald Kommers wrote with his whole attention absorbed by German constitutionalism and its animating problems and aspirations. He never wrote with a thought for himself. His scholarly aim was understanding. His practical aim, I think, was to enhance the sum of ordered liberty and human happiness in the world.

\section{Trailblazer}

Twenty years have passed since Don's jubilee reflections in the SMU Law Review. The Basic Law is now on the cusp of its seventieth birthday. Much, of course, has changed in twenty years. In retrospect, the golden anniversaries of 1999 (for the Basic Law) and 2001 (for the Court) marked a kind of apogee. As the seventieth anniversaries approach it will be hard to be quite so unstintingly celebratory as were the fin-de-millénaire encomiasts of yesteryear. Don's own jubilee piece was admiring without being effusive. And yet one cannot read it without reflecting on how much has changed. There is almost nothing in the piece about the constitutional challenges of globalization, Europeanization, and their discontents. Don lived long enough to see that discontent grow in ominous ways. And yet my own view, perhaps overly optimistic, is that the institutions Don analyzed so astutely will prove more resilient than many now fear-and for many of the reasons that Don identified. Indeed, the survival and strength of constitutionalism and constitutional justice in Europe and beyond will likely owe something to the work of dedicated scholars like Donald Kommers.

I owe Don much indeed. We all do. He labored with the German materials for years, even decades, when almost no one else in the English-speaking world was attending to German constitutionalism and few political scientists were attending to courts. He was a pioneer in both respects. I can hardly imagine the loneliness that must have sometimes accompanied Don's herculean efforts. But Don knew he had landed on something remarkable, and he seemed to sense that if he could simply articulate what he had found-patiently and methodically, with elegance and grace-his scholarly fellow citizens would eventually take note.

They-we-certainly have taken note. The very existence of The German Law Journal is a testament to Don's enormous influence and success. That influence will expand with time. Every scholar stands on the shoulders of giants. In our growing field, Don's shoulders are sweeping and solid. We will miss him. We miss him already. But we will carry on the work that he began.

\footnotetext{
${ }^{8}$ William Hazlitt, On Old English Writers and Speakers, in 1 William Hazlitt, Table TalK: Opinions On BoOKs, Men, AND Things 188, 198 (1845).
}

Cite this article: Collings J (2019). Donald P. Kommers: Teacher, Translator, Trailblazer. German Law Journal 20, $583-585$. https://doi.org/10.1017/glj.2019.42 